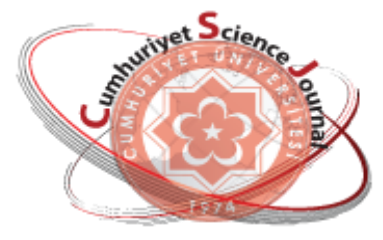

(8)

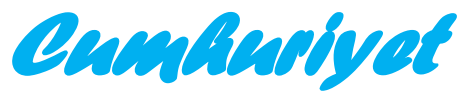

$\cos$

e-ISSN: $2587-246 X$

ISSN: 2587-2680

Cumhuriyet Sci. J., Vol.38-4 (2017) 661-673

\title{
Computational Investigations on IR, UV-VIS and NMR Spectra of Copper(II) Phenanthroline Complexes with DFT Method
}

\author{
Koray SAYIN \\ Department of Chemistry, Faculty of Science, Cumhuriyet University, 58140 Sivas, Turkey
}

Received: 04.05.2017; Accepted: 16.08.2017

http://dx.doi.org/10.17776/csj.349259

\begin{abstract}
Computational investigations were done on two $\mathrm{Cu}(\mathrm{II})$ complexes. There is no any data or spectral results of them in literature. In this paper, B3LYP one of the hybrid DFT functions was selected for mentioned complexes. Optimized structures, IR, UV-VIS and NMR spectrum of studied complexes were calculated and were calculated and examined in detail. Additionally, molecular electrostatic potential (MEP) maps, MEP contours and single occupied molecular orbitals (SOMO) were analyzed. Interaction energies between ligands and the metal atom, formation enthalpies and formation Gibbs free energies were investigated. Geometric structure and structural parameters were determined by computational techniques and the structures were supported by spectral analyses. The most reactive regions of mentioned complexes were determined by MEP maps and MEP contours.
\end{abstract}

Keywords: $\mathrm{Cu}(\mathrm{II})$ complexes, DFT studies, Spectral Studies, MEP mapss.

\section{DFT Yöntemi ile Bakır(II) Fenantrolin Komplekslerinin IR, UV-VIS ve NMR Spektrumları Üzerine Hesaplamalı Araştırmalar}

\begin{abstract}
Özet: İki $\mathrm{Cu}(\mathrm{II})$ kompleksleri üzerine hesapsal araştırmalar yapıldı. Literatürde, bu kompleksler hakkında herhangi bir bilgi yada spektral sonuçlar yoktur. Bu çalışmada, hibrit DFT fonksiyonellerinden biri olan B3LYP söz konusu komplekslerin hesaplarında kullanıldı. Söz konusu komplekslerin optimize yapıları hesaplandı ve IR, UV-VIS ve NMR spektrumları hesaplandı ve detaylı bir şekilde incelendi. İlaveten, doğrusal olmayan optik özellikler, moleküler elektrostatik potansiyel (MEP) haritaları, MEP konturları ve tek dolu moleküler orbitalleri analiz edildi. Ligand ve metal atom arasındaki etkileşim enerjileri, oluşum entalpileri ve Gibbs serbest enerjisi araştırıldı. Geometrik yapı ve yapısal parametreler hesapsal tekniklerle belirlendi ve komplekslerin yapıları spektral analizler ile desteklendi. Söz konusu komplekslerin en aktif bölgeleri MEP haritaları ve MEP kontorları ile belirlendi.
\end{abstract}

Anahtar Kelimeler: $\mathrm{Cu}(\mathrm{II})$ kompleksleri, DFT çalışması, Spektral çalışma, MEP haritası.

\section{INTRODUCTION}

New Schiff bases and their complexes are currently attracting the attention of medical chemistry [1-6]. Metal complexes are known to accelerate the drug interaction with appropriate structure and the efficiency of a therapeutic agent can often be increased upon coordination with metal ions [7]. Pharmacological activity has also been obtained to be highly dependent on environment and nature of the center atom and donor sequence of the ligands as different ligands exhibit different biological reactivity.

Biological reactivities of two ligands $\left(\mathrm{L}^{1}\right.$ and $\left.\mathrm{L}^{2}\right)$ and their two complexes $\left(\left[\mathrm{CuL}^{1}(\mathrm{phen})_{2}\right]\right.$ and $\left.\left[\mathrm{CuL}^{2}(\text { phen })_{2}\right]\right)$ have been investigated towards some bacterias which are (S. aureus,

\footnotetext{
* Corresponding author. Email address: krysayin@gmail.com or ksayin@cumhuriyet.edu.tr

http://dergipark.gov.tr/csj (C2016 Faculty of Science, Cumhuriyet University
} 
K. pneumonia, E. coli, P. aeruginosa, S. podity) and some fungus which are (A. niger, F. solani, C. lunata, R. bataicola, C. albicans) by Raman and Mahalakshmi in 2014 [8]. Schematic diagram of investigated complexes is represented in Scheme 1. Additionally,
[ZnL1(phen)2],

[ZnL2(phen)2], [NiL1(phen)2] and [NiL2(phen)2] complexes have been studied as computationally by Sayin et. al in 2015 [9]. However, there is no any data about studied complexes in literature.<smiles>[R]OC(=O)[N+](=O)[O-]</smiles>

L Ligands

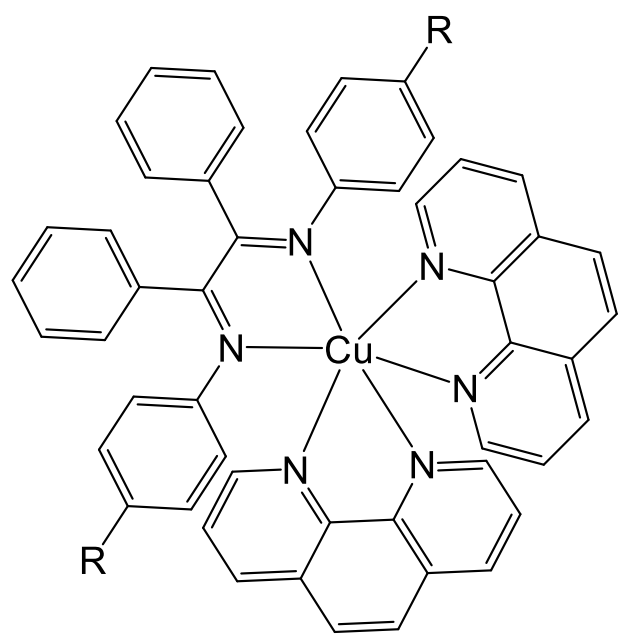

Copper Complexes

Scheme 1. Schematic diagram of studied $\mathrm{Cu}$ (II) complexes.

Quantum chemical investigations are attracted the interest of researchers and have been popular in recent years [10-14]. The goal of this paper, the structures of investigated complexes is firstly determined at the B3LYP method and geometric parameters are obtained from the optimized structure. Then, these structures are supported by IR and NMR spectrum. Additionally, UV-VIS spectrum of studied complexes are calculated. The single occupied molecular orbital (SOMO), molecular electrostatic potential (MEP) maps and MEP contours are investigated and examined in detail.

\section{COMPUTATIONAL DETAILS}

All computational processes of $\mathrm{Cu}$ (II) complexes were performed by using GaussView 5.0.8 [15], Gaussian 09 AML64G09 Revision-C01 programs [16] and ChemBioDraw Ultra Version (13.0.0.3015)
[17]. Firstly, geometries of investigated complexes were fully optimized by using UFF force field which is one of the molecular mechanics methods [18]. UFF calculations were performed to gaining job time and prevent convergence problems at mentioned level. After that, the geometries of mentioned complexes reoptimized at density functional theory (DFT) method which is B3LYP $[19,20]$ methods with LANL2DZ [21-23] for metal atoms and $6-31 \mathrm{G}(\mathrm{d}, \mathrm{p})$ basis set for the rest atoms in complex structures. The vibrational frequency analyses indicate that optimized structures of relevant complexes were at stationary points corresponding to local minima without imaginary frequencies. Time dependent-density functional theory (TDDFT) method was used for UV-VIS spectra calculations and GIAO method for NMR calculations of mentioned complexes. 
Tetramethylsilane (TMS) was used as the reference substance for NMR calculations.

\section{RESULTS and DISCUSSION}

3.1. Optimized Structures Thermodynamic Parameters
The fully optimizations are done on $\left[\mathrm{CuL}^{1}(\text { phen })_{2}\right]$ (1) and $\left[\mathrm{CuL}^{2}(\text { phen })_{2}\right]$ (2) by using UFF and B3LYP methods with GEN keyword in vacuo. The optimized structures of complex (1) and complex (2) are presented in and Fig. 1. In these figures, hydrogen atoms are omitted for clarity. Additionally, calculated structural parameters of investigated complexes are given in Table 1.

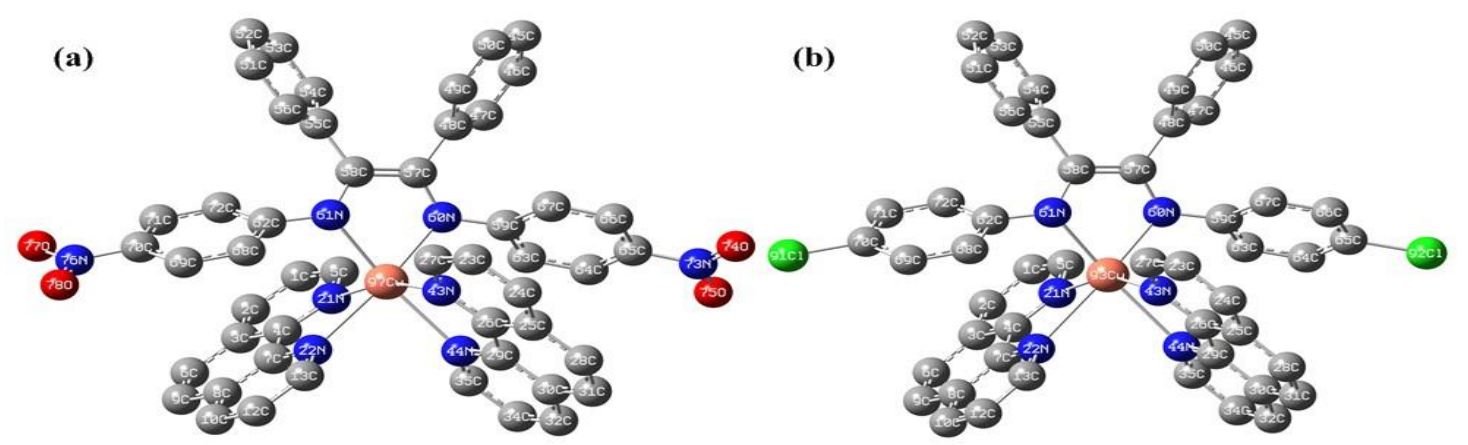

Figure 1. Optimized structures of (a) $\left[\mathrm{CuL}^{1}(\text { phen })_{2}\right]$ and (b) $\left[\mathrm{CuL}^{2}(\mathrm{phen})_{2}\right]$ complexes at B3LYP method in vacuum with atomic labelling.

Table 1. The calculated structural parameters of mentioned complexes at B3LYP method with mix basis set in vacuum.

\begin{tabular}{rll}
\hline & Complex (1) & Complex (2) \\
\hline Bond Lengths $(\AA)$ & & \\
\hline $\mathrm{Cu}-21 \mathrm{~N}$ & 2.297 & 2.237 \\
$\mathrm{Cu}-22 \mathrm{~N}$ & 2.442 & 2.588 \\
$\mathrm{Cu}-43 \mathrm{~N}$ & 2.298 & 2.239 \\
$\mathrm{Cu}-44 \mathrm{~N}$ & 2.442 & 2.57 \\
$\mathrm{Cu}-60 \mathrm{~N}$ & 2.223 & 2.198 \\
$\mathrm{Cu}-61 \mathrm{~N}$ & 2.223 & 2.195 \\
\hline Bond Angles $\left(^{\circ}\right)$ & & \\
\hline $21 \mathrm{~N}-\mathrm{Cu}-22 \mathrm{~N}$ & 70.3 & 68.8 \\
$21 \mathrm{~N}-\mathrm{Cu}-43 \mathrm{~N}$ & 162.9 & 156 \\
$21 \mathrm{~N}-\mathrm{Cu}-44 \mathrm{~N}$ & 96.5 & 92.4 \\
$21 \mathrm{~N}-\mathrm{Cu}-60 \mathrm{~N}$ & 98.1 & 100.8 \\
$21 \mathrm{~N}-\mathrm{Cu}-61 \mathrm{~N}$ & 95.5 & 98 \\
$22 \mathrm{~N}-\mathrm{Cu}-43 \mathrm{~N}$ & 96.5 & 91.9 \\
$22 \mathrm{~N}-\mathrm{Cu}-44 \mathrm{~N}$ & 82.4 & 78.7 \\
$22 \mathrm{~N}-\mathrm{Cu}-60 \mathrm{~N}$ & 168.1 & 169.6 \\
$22 \mathrm{~N}-\mathrm{Cu}-61 \mathrm{~N}$ & 102.1 & 103.6 \\
$43 \mathrm{~N}-\mathrm{Cu}-44 \mathrm{~N}$ & 70.3 & 69.1 \\
$43 \mathrm{~N}-\mathrm{Cu}-60 \mathrm{~N}$ & 95.4 & 98.2 \\
$43 \mathrm{~N}-\mathrm{Cu}-61 \mathrm{~N}$ & 98.1 & 100.5 \\
$44 \mathrm{~N}-\mathrm{Cu}-60 \mathrm{~N}$ & 102.1 & 102.8 \\
$44 \mathrm{~N}-\mathrm{Cu}-61 \mathrm{~N}$ & 168.1 & 169.5 \\
$60 \mathrm{~N}-\mathrm{Cu}-61 \mathrm{~N}$ & 75.7 & 76.9 \\
\hline
\end{tabular}


According to the calculation results, there are six coordinate-covalent bonds around the copper atom in complexes. Interaction energies ( $\left.\mathrm{E}_{\text {Interaction }}\right)$, formation enthalpies

$$
\begin{aligned}
& E_{\text {Interaction }}=E_{\text {Complex }}-\left(E_{\text {Metal }}+E_{\text {Ligand }}\right) \\
& H_{\text {Formation }}=H_{\text {Complex }}-\left(H_{\text {Metal }}+H_{\text {Ligand }}\right) \\
& G_{\text {Formation }}=G_{\text {Complex }}-\left(G_{\text {Metal }}+G_{\text {Ligand }}\right)
\end{aligned}
$$

$\left(\mathrm{H}_{\text {Formation }}\right)$ and formation Gibbs free energy $\left(\mathrm{G}_{\text {Formation }}\right)$ of mentioned complexes are calculated by using Eqs. (1)-(3) and given in Table 2.

\begin{tabular}{|c|c|c|c|c|}
\hline \multicolumn{5}{|c|}{ For Interaction energies } \\
\hline & $\mathrm{E}_{\text {Complex }}{ }^{\mathrm{a}}$ & $\mathrm{E}_{\text {Metal }}{ }^{\mathrm{a}}$ & $\mathrm{E}_{\text {Ligand }}{ }^{\mathrm{a}}$ & $\mathrm{E}_{\text {Interaction }}{ }^{\mathrm{b}}$ \\
\hline Complex (1) & -2859.974420 & -195.079691 & -2663.836033 & $-2.78 \times 10^{3}$ \\
\hline Complex (2) & -3370.175243 & -195.079691 & -3173.977726 & $-2.93 \times 10^{3}$ \\
\hline \multicolumn{5}{|c|}{ For formation enthalpies } \\
\hline & $\mathrm{H}_{\text {Complex }} \mathrm{a}$ & $\mathrm{H}_{\text {Metal }}{ }^{\mathrm{a}}$ & $\mathrm{H}_{\text {Ligand }}{ }^{\mathrm{a}}$ & $\mathrm{H}_{\text {Formation }}^{\mathrm{b}}$ \\
\hline Complex (1) & -2859.973475 & -195.078727 & -2662.833199 & $-5.41 \times 10^{3}$ \\
\hline Complex (2) & -3370.174299 & -195.078727 & -3173.974892 & $-2.94 \times 10^{3}$ \\
\hline \multicolumn{5}{|c|}{ For formation Gibbs free energies } \\
\hline Complex (1) & $\begin{array}{l}\mathrm{G}_{\text {Complex }}{ }^{\mathrm{a}} \\
-2860.124723 \\
-3370318803\end{array}$ & $\begin{array}{l}\mathrm{G}_{\text {Metal }}{ }^{\mathrm{a}} \\
-195.097596 \\
-195097596\end{array}$ & $\begin{array}{l}\mathrm{G}_{\text {Ligand }}{ }^{\mathrm{a}} \\
-2664.013707 \\
-3174150337\end{array}$ & $\begin{array}{l}\mathrm{G}_{\text {Formation }}{ }^{\mathrm{b}} \\
-2.66 \times 10^{3} \\
-281 \times 10^{3}\end{array}$ \\
\hline
\end{tabular}

Table 2. Interaction energies ( $\mathrm{E}_{\text {Interaction }}$, formation enthalpies ( $\left.\mathrm{H}_{\text {Formation }}\right)$ and formation Gibbs free energy ( $\left.\mathrm{G}_{\text {Formation }}\right)$ of mentioned complexes at B3LYP/6-31G(d,p)(LANL2DZ).

${ }^{\mathrm{a}}$ in atomic unit, ${ }^{\mathrm{b}}$ in $\mathrm{kj} \mathrm{mol}^{-1}$

According to the Table 2, interaction energies, formation enthalpies and formation Gibbs free energies are lower than zero. These results mean that formations of mentioned complexes are spontaneous and exothermic processes.

\subsection{IR Spectra}

In complex (1) and (2), there are 97 and 93 atoms, respectively. The number of active observable fundamentals of a non-linear molecule which contains $\mathrm{N}$ atoms is equal to (3N-6). Hence, 285 and 273 normal modes of vibration are calculated for complex (1) and (2), respectively under $\mathrm{C} 1$ point group symmetry. Harmonic vibrational frequencies are calculated by using computational chemistry methods. Calculated frequencies are not scaled any factor. Some harmonic frequencies which have the higher intensity than $50 \mathrm{~km} \mathrm{~mol}^{-1}$ are examined in detail and these results are given in Tables 3 and 4 for complex (1) and (2), respectively. IR spectra of complex (1) and (2) are represented in Fig. 2(a) and 2(b), respectively. 


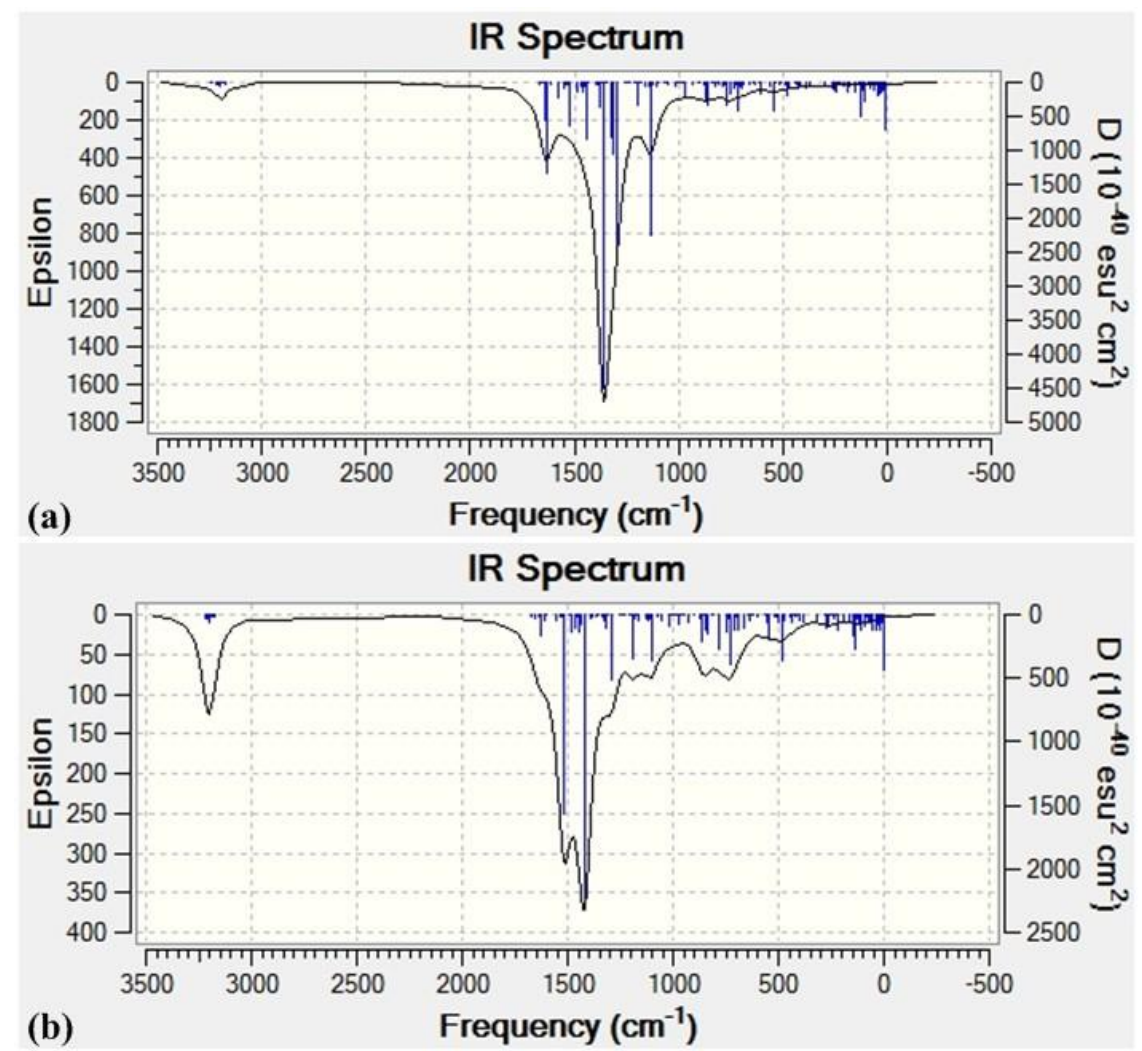

Figure 2. IR spectra of (a) complex (1) and (b) complex (2) at same level of theory in vacuo.

Table 3. Harmonic vibrational frequencies of complex (1) at B3LYP method in gas phase.

\begin{tabular}{llll}
\hline Mode & Frequency & Intensity $^{\mathrm{a}}$ & Assignments \\
\hline 76 & 546 & 56.8621 & $\omega_{\mathrm{C}-\mathrm{H}}$ \\
98 & 720 & 72.8322 & $\omega_{\mathrm{C}-\mathrm{H}}$ \\
106 & 765 & 66.5457 & $\omega_{\mathrm{C}-\mathrm{H}}$ \\
122 & 862 & 69.6999 & $\omega_{\mathrm{C}-\mathrm{H}}, v_{\mathrm{C}-\mathrm{N}}$ \\
126 & 866 & 58.9163 & $\omega_{\mathrm{C}-\mathrm{H}}, v_{\mathrm{C}-\mathrm{N}}$ \\
136 & 971 & 57.2214 & $v_{\mathrm{C}=\mathrm{C}}, \omega_{\mathrm{C}-\mathrm{H}}$ \\
170 & 1129 & 147.415 & $\gamma_{\mathrm{C}-\mathrm{H}}$ \\
172 & 1133 & 640.4009 & $v_{\mathrm{C}-\mathrm{N}}, \gamma_{\mathrm{C}-\mathrm{H}}$ \\
173 & 1196 & 99.8947 & $\gamma_{\mathrm{C}-\mathrm{H}}, v_{\mathrm{C}-\mathrm{N}}$ \\
194 & 1296 & 870.2322 & $v_{\mathrm{C}-\mathrm{N}}, \gamma_{\mathrm{C}-\mathrm{H}}$ \\
196 & 1316 & 350.5012 & $\gamma_{\mathrm{C}-\mathrm{H}}$ \\
198 & 1328 & 270.3557 & $v_{\mathrm{C}=\mathrm{C}}, \omega_{\mathrm{C}-\mathrm{H}}$ \\
202 & 1357 & 1436.2881 & $v_{\mathrm{C}=\mathrm{C}}, v_{\mathrm{N}=\mathrm{O}}, \gamma_{\mathrm{C}-\mathrm{H}}$ \\
203 & 1359 & 1055.3766 & $\gamma_{\mathrm{C}-\mathrm{H}}, v_{\mathrm{N}=\mathrm{O}}, v_{\mathrm{C}-\mathrm{N}}$ \\
205 & 1361 & 1537.638 & $v_{\mathrm{C}=\mathrm{C}}, v_{\mathrm{N}=\mathrm{O}}$ \\
208 & 1376 & 121.3688 & $v_{\mathrm{N}=\mathrm{O}}$ \\
214 & 1442 & 297.1527 & $v_{\mathrm{C}-\mathrm{N}}$ \\
218 & 1461 & 50.6319 & $\gamma_{\mathrm{C}-\mathrm{H}}$ \\
222 & 1486 & 52.8916 & $\gamma_{\mathrm{C}-\mathrm{H}}$ \\
226 & 1521 & 245.2443 & $\gamma_{\mathrm{C}-\mathrm{H}}, v_{\mathrm{C}=\mathrm{C}}$ \\
234 & 1576 & 87.5921 & $v_{\mathrm{N}=\mathrm{O}}, v_{\mathrm{C}=\mathrm{C}}$ \\
238 & 1627 & 91.3218 & $v_{\mathrm{C}=\mathrm{C}}, \gamma_{\mathrm{C}-\mathrm{H}}$ \\
240 & 1634 & 549.3618 & $v_{\mathrm{C}=\mathrm{C}}, v_{\mathrm{N}=\mathrm{O}}$ \\
242 & 1638 & 231.2338 & $v_{\mathrm{C}=\mathrm{C}}, v_{\mathrm{N}=\mathrm{O}}$ \\
245 & 1642 & 64.519 & $v_{\mathrm{C}=\mathrm{C}}, v_{\mathrm{N}=\mathrm{O}}$ \\
\hline
\end{tabular}

Vibration modes: $v$, stretching; $\gamma$, rocking; $\omega$, wagging. ${ }^{a}$ in $\mathrm{km} \mathrm{mol}^{-1}$ 
Table 4. Harmonic vibrational frequencies of complex (2) at B3LYP method in gas phase.

\begin{tabular}{llll}
\hline Mode & Frequency & Intensity $^{\mathrm{a}}$ & Assignments \\
\hline 95 & 725 & 71.0678 & $\omega_{\mathrm{C}-\mathrm{H}}$ \\
105 & 785 & 53.6326 & $\omega_{\mathrm{C}-\mathrm{H}}$ \\
158 & 1103 & 99.9776 & $v_{\mathrm{C}-\mathrm{Cl}}, v_{\mathrm{C}=\mathrm{C},}, \gamma_{\mathrm{C}-\mathrm{H}}$ \\
172 & 1186 & 104.6714 & $\gamma_{\mathrm{C}-\mathrm{H}}, v_{\mathrm{C}-\mathrm{N}}$ \\
184 & 1289 & 166.6803 & $v_{\mathrm{C}-\mathrm{C}}, v_{\mathrm{C}-\mathrm{N}}$, \\
202 & 1419 & 806.6099 & $v_{\mathrm{C}-\mathrm{N}}, \gamma_{\mathrm{C}-\mathrm{H}}, v_{\mathrm{C}=\mathrm{C}}$ \\
212 & 1484 & 51.1067 & $\gamma_{\mathrm{C}-\mathrm{H}}, v_{\mathrm{C}=\mathrm{C}}$ \\
216 & 1517 & 593.3464 & $\gamma_{\mathrm{C}-\mathrm{H}}, v_{\mathrm{C}=\mathrm{C}}$ \\
230 & 1631 & 69.2755 & $v_{\mathrm{C}=\mathrm{C}}$ \\
256 & 3196 & 51.1024 & $v_{\mathrm{C}=\mathrm{H}}$ \\
\hline
\end{tabular}

Vibration modes: $v$, stretching; $\gamma$, rocking; $\omega$, wagging. ${ }^{a}$ in $\mathrm{km} \mathrm{mol}^{-1}$

\subsection{Molecular Electrostatic Potential (MEP) Maps, MEP Contours and Single Occupied Molecular Orbital}

Different values of the electrostatic potential at MEP map are represented by different colors which are red, yellow, green, light blue and blue. The red and yellow regions in MEP map are related to higher electron density, while light blue and blue regions in MEP map is related to lower electron density. In MEP contours, there are two color lines which are yellow and red and these line related to positive charges and negative charges, respectively. Additionally, the steric effect can be easily seen from MEP contour. MEP maps and contours are represented in Fig. 3.
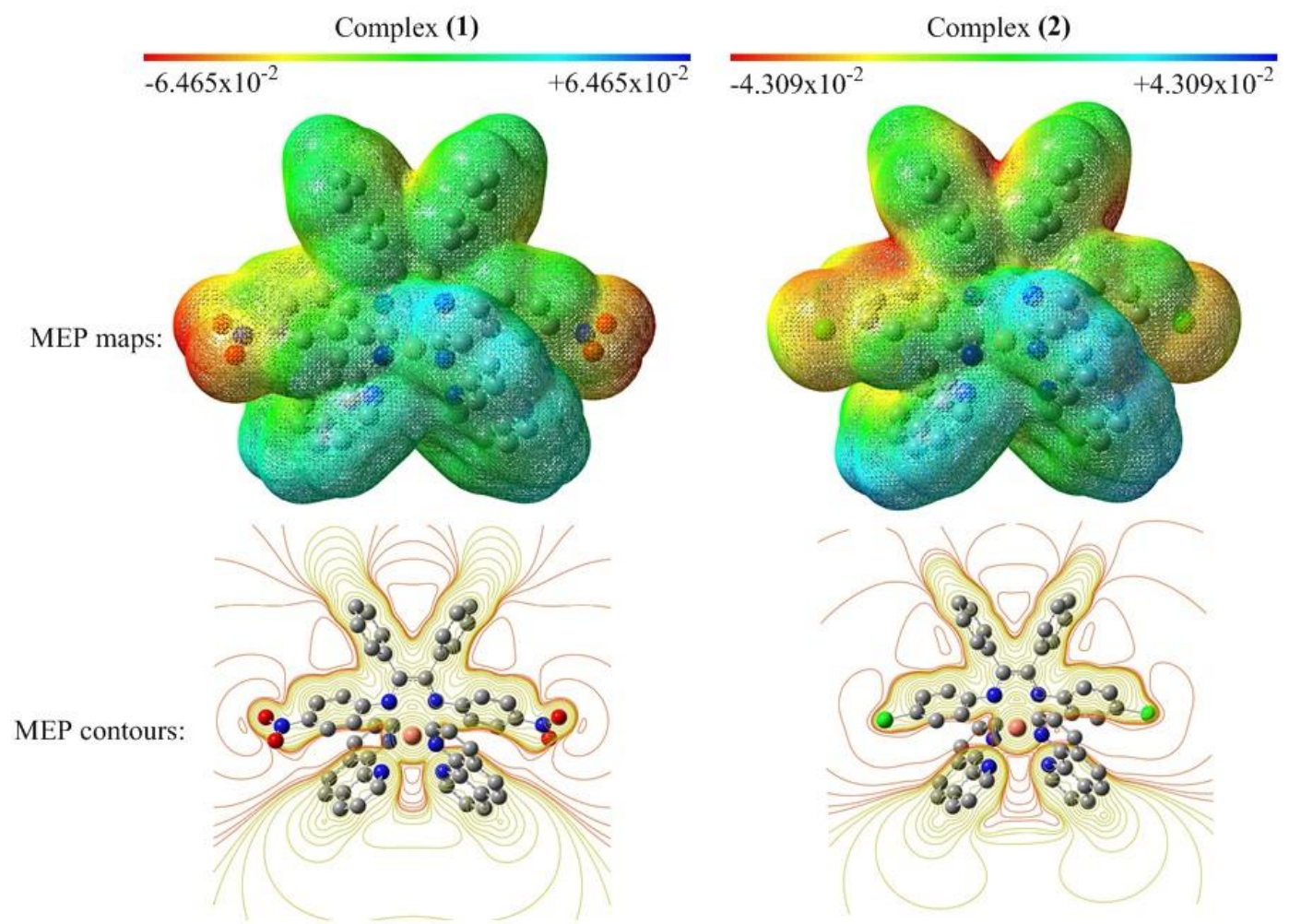

Figure 3. MEP maps and contours of mentioned complexes at B3LYP method in gas phase. 
Electrons are more intense on $-\mathrm{NO}_{2}$ group than rest atoms or groups in complex (1). As for the complex (2), electrons are more intense on benzene rings which belong to $\mathrm{L}^{2}$ ligand than rest of the complex. A part of molecular orbital (MO) energy diagram of complex (1) and (2) are given in Figs. 4 and 5 , respectively. Degeneracy tolerance is taken as $2.6255 \mathrm{~kJ} \mathrm{~mol}^{-1}$ in these diagrams. This value means that if energy difference between molecular orbitals is equal or lower than $2.6255 \mathrm{~kJ} \mathrm{~mol}^{-1}$, these molecular orbitals are taken as identical orbitals. According to this figure, 221 alpha-MO in complex (1) and 215 alpha-MO in complex (2) are single occupied molecular orbitals (SOMOs). Additionally, 219 and 220 alphaMO are equivalent in complex (1) while 213 and 214 alpha-MO are equivalent in complex (2). Contour diagrams of SOMOs which belong to complex (1) and (2) are represented in Fig. 6.

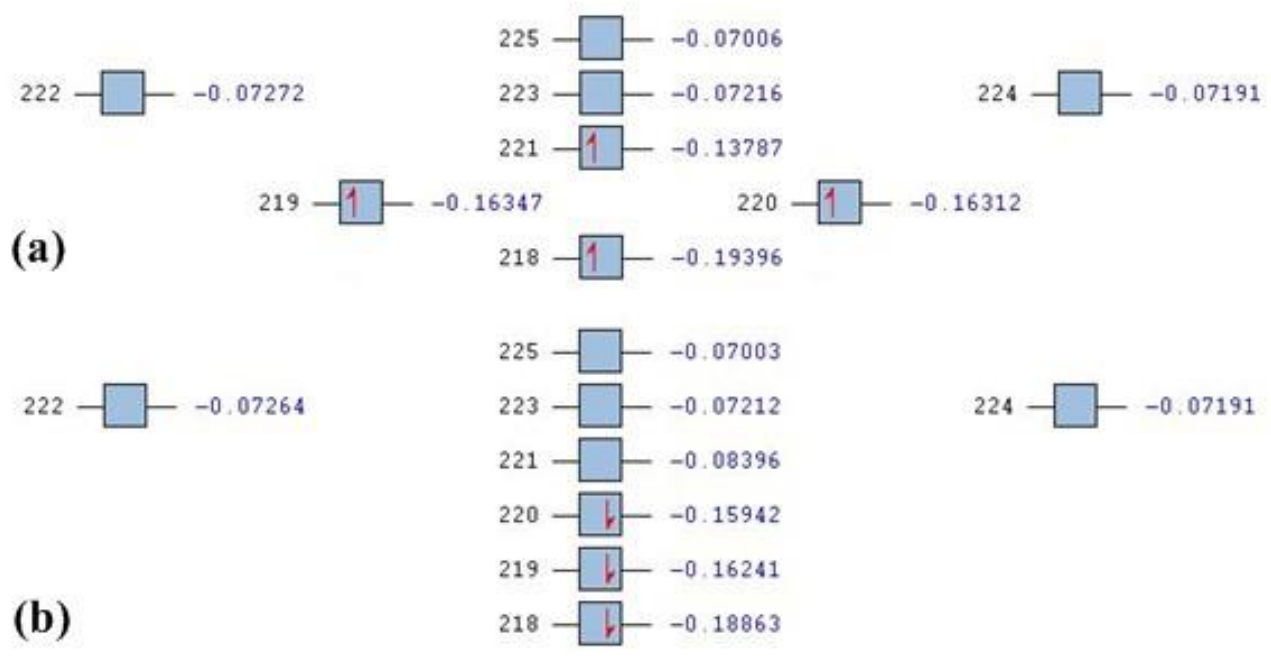

Figure 4. Energy diagrams of (a) alpha molecular orbitals and (b) beta molecular orbitals of complex (1) at same level of theory.

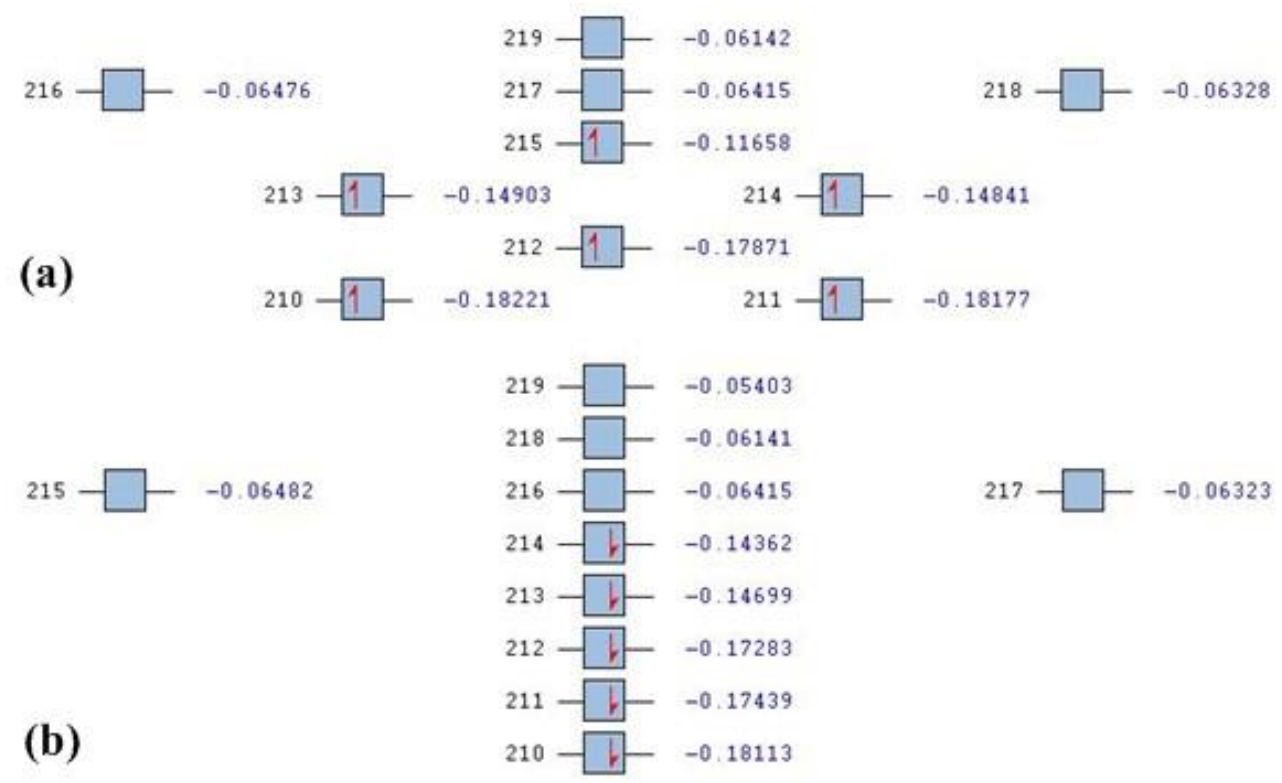

Figure 5. (a) alpha molecular orbitals and (b) beta molecular orbitals energy diagrams of complex (2) at same level of theory. 
Complex (1)

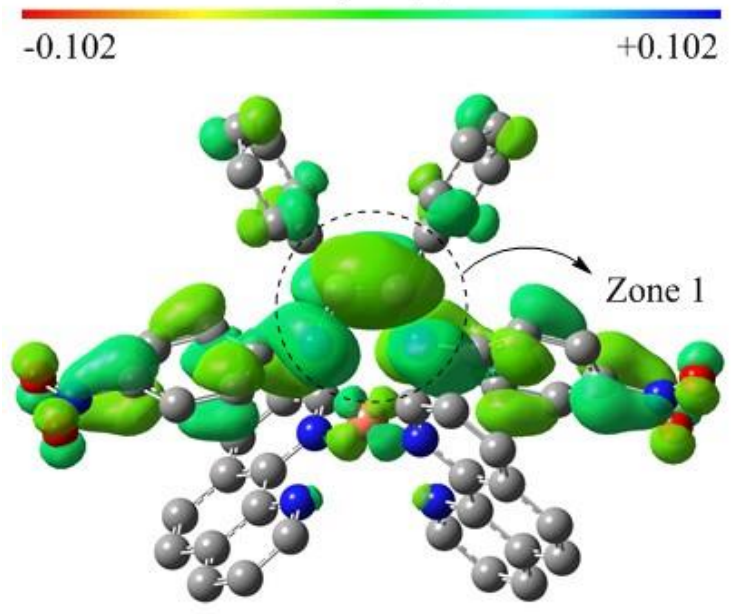

Complex (2)

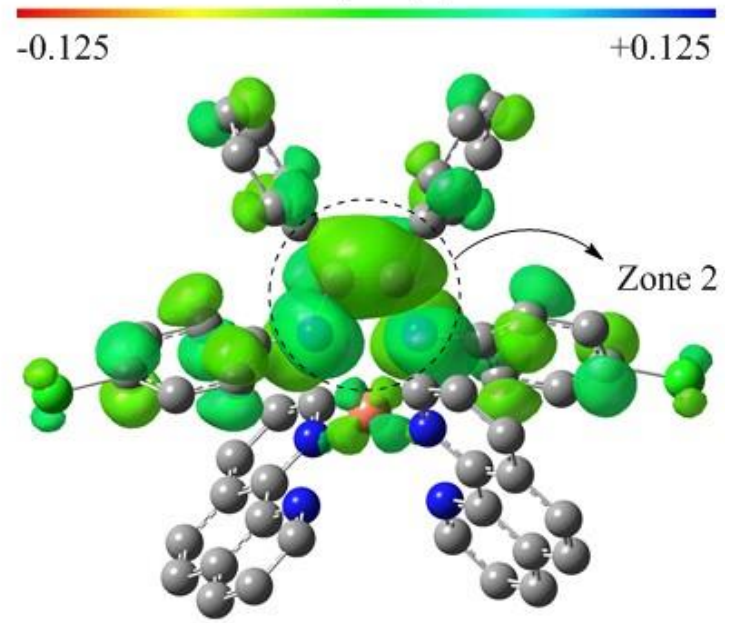

Figure 6. Contour diagrams of SOMOs for complex (1) and (2) at B3LYP method in gas phase.

According to Fig. 6, the electron of SOMO is mainly delocalized on $\mathrm{L}^{1}$ and $\mathrm{L}^{2}$ ligands in complex (1) and (2), respectively. Different values of electron density on contour diagrams are presented by different colors. Additionally, there are different lobes which have the different size in contour diagrams. Size variation means that electrons are more localized in big lobe than small lobe. As a result, SOMO electron is mainly localized on zone 1 and zone 2 in $\mathrm{L}^{1}$ and $\mathrm{L}^{2}$ ligands, respectively.

\subsection{UV-VIS Spectra}

UV-VIS spectra of mentioned complexes are calculated by using time - dependent (TD) B3LYP method with 6-31G(d,p)(LANL2DZ) basis set in the gas phase. Calculated UV-VIS spectra of mentioned complexes are represented in Fig. 7.
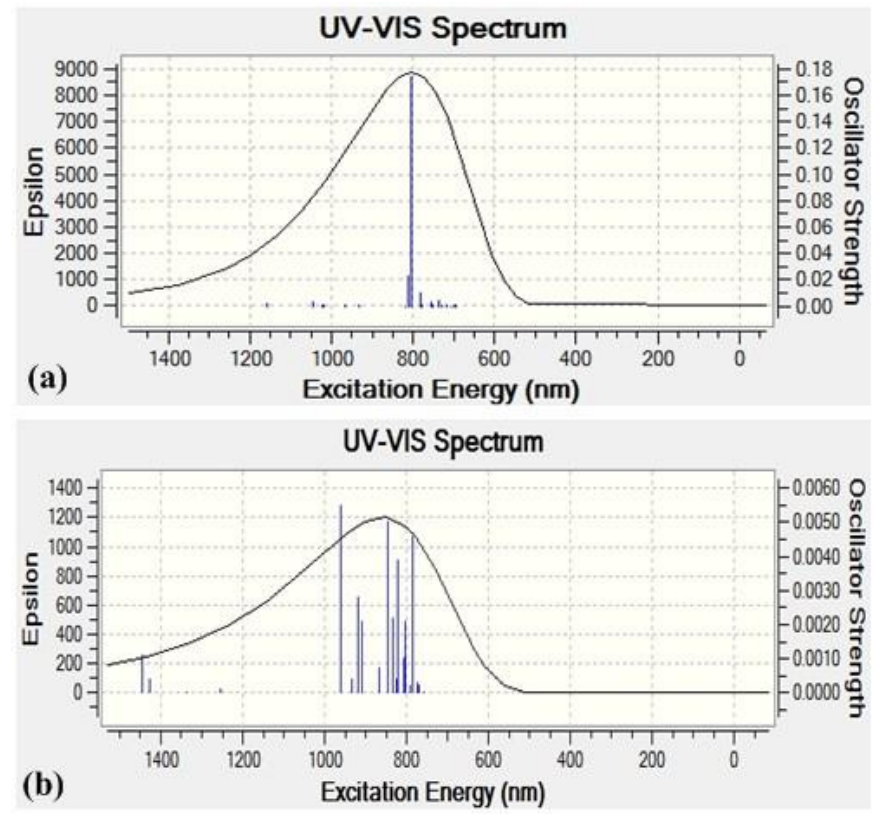

Figure 7. Calculated UV-VIS spectra of (a) complex (1) and (b) complex (2) at TD-B3LYP method in gas phase. 
According to mentioned figure, main band for complex (1) is mainly occurred from a peak which wavelength is $803.4 \mathrm{~nm}$, while main band for complex (2) is mainly occurred from three peaks. Their wavelengths are 962.3, 846.9 and $785.1 \mathrm{~nm}$ which have higher intensity than 1000 Epsilon. Each peak occurs from many electronic transitions. These transitions and their percentage of transition character $(\mathrm{TC} \%)$ are given in Table 5 . TC\% are calculated by using Eq. (4) [24-27].

$$
\mathrm{TC} \%=\frac{\mathrm{t}^{2}}{\Sigma \mathrm{t}^{2}} \times 100
$$

where $t$ is coefficient of the wavefunction for each excitation and $\Sigma \mathrm{t}^{2}$ is the sum of the squares of all coefficient of the wavefunction for each excitation in a specific band.

Table 5. Ground state and excited state for main peak in complex (2) - (6), contribution values of relevant transitions and transition types of main peak.

\begin{tabular}{|c|c|c|c|c|c|}
\hline Complexes & $\begin{array}{l}\text { Wavelength } \\
(\mathrm{nm})\end{array}$ & Ground State & Excited State & Contribution $\%$ & $\begin{array}{l}\text { Transition } \\
\text { Type }\end{array}$ \\
\hline \multirow{3}{*}{ Complex (1) } & \multirow{3}{*}{803.4} & $221 \alpha$ & $226 \alpha$ & 80.14 & $\mathrm{~L} \rightarrow \mathrm{L}^{\mathrm{a}}$ \\
\hline & & $220 \beta$ & $223 \beta$ & 18.55 & $\mathrm{~L} \rightarrow \mathrm{L}^{\mathrm{a}}$ \\
\hline & & $220 \beta$ & $226 \beta$ & 1.31 & $\mathrm{~L} \rightarrow \mathrm{L}^{\mathrm{a}}$ \\
\hline \multirow{21}{*}{ Complex (2) } & \multirow{9}{*}{785.1} & $213 \alpha$ & $216 \alpha$ & 16.57 & MLCT $^{b}$ \\
\hline & & $213 \alpha$ & $218 \alpha$ & 6.62 & $\mathrm{MLCT}^{\mathrm{b}}$ \\
\hline & & $213 \alpha$ & $219 \alpha$ & 1.99 & $\mathrm{MLCT}^{\mathrm{b}}$ \\
\hline & & $214 \alpha$ & $216 \alpha$ & 28.41 & $\mathrm{~L} \rightarrow \mathrm{L}^{\mathrm{a}}$ \\
\hline & & $214 \alpha$ & $218 \alpha$ & 1.33 & $\mathrm{~L} \rightarrow \mathrm{L}^{\mathrm{a}}$ \\
\hline & & $213 \beta$ & $215 \beta$ & 1.30 & $\mathrm{~L} \rightarrow \mathrm{L}^{\mathrm{a}}$ \\
\hline & & $213 \beta$ & $216 \beta$ & 3.30 & $\mathrm{~L} \rightarrow \mathrm{L}^{\mathrm{a}}$ \\
\hline & & $213 \beta$ & $217 \beta$ & 6.81 & $\mathrm{~L} \rightarrow \mathrm{L}^{\mathrm{a}}$ \\
\hline & & $214 \beta$ & $218 \beta$ & 33.76 & $\mathrm{~L} \rightarrow \mathrm{L}^{\mathrm{a}}$ \\
\hline & \multirow{9}{*}{846.9} & $213 \alpha$ & $216 \alpha$ & 27.18 & $\mathrm{MLCT}^{\mathrm{b}}$ \\
\hline & & $213 \alpha$ & $219 \alpha$ & 7.27 & MLCT $^{\mathrm{b}}$ \\
\hline & & $214 \alpha$ & $216 \alpha$ & 26.81 & $\mathrm{~L} \rightarrow \mathrm{L}^{\mathrm{a}}$ \\
\hline & & $214 \alpha$ & $218 \alpha$ & 12.83 & $\mathrm{~L} \rightarrow \mathrm{L}^{\mathrm{a}}$ \\
\hline & & $214 \alpha$ & $219 \alpha$ & 7.55 & $\mathrm{~L} \rightarrow \mathrm{L}^{\mathrm{a}}$ \\
\hline & & $213 \beta$ & $215 \beta$ & 2.60 & $\mathrm{~L} \rightarrow \mathrm{L}^{\mathrm{a}}$ \\
\hline & & $213 \beta$ & $217 \beta$ & 1.81 & $\mathrm{~L} \rightarrow \mathrm{L}^{\mathrm{a}}$ \\
\hline & & $213 \beta$ & $219 \beta$ & 12.88 & $\mathrm{~L} \rightarrow \mathrm{L}^{\mathrm{a}}$ \\
\hline & & $214 \beta$ & $216 \beta$ & 1.07 & $\mathrm{~L} \rightarrow \mathrm{L}^{\mathrm{a}}$ \\
\hline & \multirow{3}{*}{962.3} & $214 \beta$ & $215 \beta$ & 29.09 & $\mathrm{~L} \rightarrow \mathrm{L}^{\mathrm{a}}$ \\
\hline & & $214 \beta$ & $218 \beta$ & 6.73 & $\mathrm{~L} \rightarrow \mathrm{L}^{\mathrm{a}}$ \\
\hline & & $214 \beta$ & $219 \beta$ & 64.18 & $\mathrm{~L} \rightarrow \mathrm{L}^{\mathrm{a}}$ \\
\hline
\end{tabular}

${ }^{\text {a }}$ Ligand to ligand charge transfer

${ }^{\mathrm{b}}$ Metal to ligand charge transfer

Contour diagrams of molecular orbitals given in Table 5 are used for determination of transition type and these diagrams are given in supplementary material. According Table 5, main bands in UV-VIS spectra of complex (1) and (2) are mainly occurred from ligand to ligand charge transfer (LLCT).

\section{5. ${ }^{1} \mathrm{H}$ - and ${ }^{13} \mathrm{C}$-NMR Spectra}

Chemical shifts in NMR spectra are recognized as an important part of the information contained and these data are valuable for structural interpretation due to their sensitivity to structural changes. Experimental NMR results of mentioned complexes are not given in literature. NMR spectra of mentioned copper(II) complexes are calculated at GIAO-B3LYP/6- 
31G(d,p)(LANL2DZ) level in vacuum. Tetramethylsylane (TMS) is used as reference substance. TMS therefore is optimized at B3LYP/6-31G(d,p) level and chemical shifts of TMS are obtained at GIAO-B3LYP/6-31G(d,p) level. In all TMS calculations, $\mathrm{T}_{\mathrm{d}}$ point group is defined. Chemical shift $(\delta)$ values are calculated by using Eq. (5) [28],

$$
\delta=\delta_{T M S}-\delta_{\text {OUT }}
$$

where $\delta$ is chemical shift value in ppm, $\delta_{\mathrm{TMS}}$ is the TMS reference and $\delta_{\text {out }}$ is the value read from the Gaussian output file. Calculated chemical shift values of carbon atoms and hydrogen atoms are given in Table 6 and 7 for complex (1) and (2).

Table 6. The calculated chemical shifts values of carbon atoms in ${ }^{13} \mathrm{C}-\mathrm{NMR}$ spectra for mentioned complexes.

\begin{tabular}{llllll}
\hline Atoms $^{\mathrm{a}}$ & Complex (1) & Complex (2) & Atoms $^{\mathrm{a}}$ & Complex (1) & Complex (2) \\
\hline $1 C$ & 88.4757 & 88.6398 & $46 C$ & 90.9102 & 90.3029 \\
$2 C$ & 99.4719 & 98.7205 & $47 C$ & 95.5203 & 96.0637 \\
$3 C$ & 93.2863 & 93.1955 & $48 C$ & 104.4518 & 105.4741 \\
$4 C$ & 108.4021 & 108.0543 & $49 C$ & 97.3111 & 97.7514 \\
$5 C$ & 112.4217 & 113.5407 & $50 C$ & 90.6922 & 90.1842 \\
$6 C$ & 91.3248 & 91.1835 & $51 C$ & 90.9102 & 90.3096 \\
$7 C$ & 108.0799 & 109.0596 & $52 C$ & 89.3399 & 87.9338 \\
$8 C$ & 93.2075 & 92.8962 & $53 C$ & 90.6908 & 90.2130 \\
$9 C$ & 91.9178 & 91.4001 & $54 C$ & 97.3118 & 97.7748 \\
$10 C$ & 99.5809 & 98.5526 & $55 C$ & 104.4537 & 105.4639 \\
$12 C$ & 87.7875 & 86.7788 & $56 C$ & 95.5216 & 96.0133 \\
$13 C$ & 111.2268 & 111.3090 & $57 C$ & 117.9581 & 116.1169 \\
$23 C$ & 88.4737 & 88.6491 & $58 C$ & 117.9675 & 115.7514 \\
$24 C$ & 99.4713 & 98.6865 & $61 C$ & 122.9481 & 117.2802 \\
$25 C$ & 93.2860 & 93.1512 & $62 C$ & 122.9556 & 117.1410 \\
$26 C$ & 108.4025 & 108.0462 & $63 C$ & 89.5888 & 90.5864 \\
$27 C$ & 112.4288 & 113.4175 & $64 C$ & 87.8713 & 90.7445 \\
$28 C$ & 91.3247 & 91.1405 & $65 C$ & 102.8512 & 94.9589 \\
$29 C$ & 108.0835 & 108.9378 & $66 C$ & 87.2228 & 90.0813 \\
$30 C$ & 93.2072 & 92.9000 & $67 C$ & 85.9891 & 87.5906 \\
$31 C$ & 91.9172 & 91.4454 & $68 C$ & 89.5826 & 90.7387 \\
$32 C$ & 99.5809 & 98.5560 & $69 C$ & 87.8722 & 90.7348 \\
$34 C$ & 87.7848 & 86.8208 & $70 C$ & 102.8499 & 94.9515 \\
$35 C$ & 111.2293 & 91.3128 & $71 C$ & 87.2240 & 90.0726 \\
$45 C$ & 89.3400 & 87.9481 & $72 C$ & 85.9881 & 87.5808 \\
\hline
\end{tabular}

${ }^{\mathrm{a}}$ These atoms are represented in Fig. 1. 
Table 7. The calculated chemical shifts values of carbon atoms in ${ }^{1} \mathrm{H}-\mathrm{NMR}$ spectra for mentioned complexes.

\begin{tabular}{llllll}
\hline Atoms $^{\mathrm{a}}$ & Complex (1) & Complex (2) & Atoms $^{\mathrm{a}}$ & Complex (1) & Complex (2) \\
\hline$(1 \mathrm{C}) H$ & 7.0496 & 7.0429 & $(46 \mathrm{C}) H$ & 6.0207 & 5.9712 \\
$(2 \mathrm{C}) H$ & 7.1836 & 7.1154 & $(47 \mathrm{C}) H$ & 6.3605 & 6.3837 \\
$(5 \mathrm{C}) H$ & 9.2785 & 9.5988 & $(49 \mathrm{C}) H$ & 5.8541 & 5.8621 \\
$(6 \mathrm{C}) H$ & 6.7208 & 6.7042 & $(50 \mathrm{C}) H$ & 5.8545 & 5.7853 \\
$(9 \mathrm{C}) H$ & 6.6259 & 6.6008 & $(51 \mathrm{C}) H$ & 6.0207 & 5.9772 \\
$(10 \mathrm{C}) H$ & 6.8833 & 6.7898 & $(52 \mathrm{C}) H$ & 5.9019 & 5.8117 \\
$(12 \mathrm{C}) H$ & 6.3819 & 6.1937 & $(53 \mathrm{C}) H$ & 5.8543 & 5.7930 \\
$(13 \mathrm{C}) H$ & 7.6286 & 7.4620 & $(54 \mathrm{C}) H$ & 5.8539 & 5.8715 \\
$(23 \mathrm{C}) H$ & 7.0495 & 7.0510 & $(56 \mathrm{C}) H$ & 6.3607 & 6.3976 \\
$(24 \mathrm{C}) H$ & 7.1834 & 7.1240 & $(63 \mathrm{C}) H$ & 6.1637 & 6.2909 \\
$(27 \mathrm{C}) H$ & 9.2797 & 9.5805 & $(64 \mathrm{C}) H$ & 6.1860 & 5.1026 \\
$(28 \mathrm{C}) H$ & 6.7206 & 6.7103 & $(66 \mathrm{C}) H$ & 5.7205 & 4.6416 \\
$(31 \mathrm{C}) H$ & 6.6258 & 6.6044 & $(67 \mathrm{C}) H$ & 4.2106 & 4.3909 \\
$(32 \mathrm{C}) H$ & 6.8831 & 6.7854 & $(68 \mathrm{C}) H$ & 6.1628 & 6.3024 \\
$(34 \mathrm{C}) H$ & 6.3814 & 6.1916 & $(69 \mathrm{C}) H$ & 6.1863 & 5.0680 \\
$(35 \mathrm{C}) H$ & 7.6274 & 7.4671 & $(71 \mathrm{C}) H$ & 5.7203 & 4.6783 \\
$(45 \mathrm{C}) H$ & 5.9021 & 5.8033 & $(72 \mathrm{C}) H$ & 4.2109 & 4.4544 \\
\hline
\end{tabular}

${ }^{\text {a }}$ These atoms are represented in Fig. 1.

Aromatic hydrogen and carbon atoms give peaks in range $8-6 \mathrm{ppm}$ and $145-110 \mathrm{ppm}$, respectively [29]. Additionally, aromatic hydrogen and carbon atoms can give peaks in range $7-4 \mathrm{ppm}$ and $111-74 \mathrm{ppm}$, respectively in transition metal complexes in which center atom is very important in determination of chemical shift values of hydrogen and carbon atoms [29]. According to Tables 6 and 7, calculated chemical shift values are appropriate with theoretical expectations. Chemical shift values of hydrogen and carbon atoms imply that electronic structures of mentioned complexes are very close to each other. Chemical shift differences between mentioned complexes comprise around $65 \mathrm{C}$ and $70 \mathrm{C}$ atoms due to the substituent effect.

\section{CONCLUSIONS}

The first calculations are performed with UFF method and the optimized structures of $\mathrm{Cu}$ (II) complexes are calculated by using B3LYP method with GEN keyword in vacuum. The structural parameters are obtained from the optimized structures. The IR spectrum for each complex is examined in detail. The electronic absorption spectra for mentioned complexes are calculated by using TD-B3LYP method with LANL2DZ for metal atoms and 6$31 \mathrm{G}(\mathrm{d}, \mathrm{p})$ for rest atoms in complexes. NMR spectra are calculated by using GIAO method and tetramethylsylane are used as reference substance. The interaction energies, formation enthalpies and formation Gibbs free energies are calculated and their values are lower than zero. These results show that formations of mentioned complexes are spontaneous and exothermic processes.

\section{Acknowledgments}

The numerical calculations reported in this paper are performed at TUBITAK ULAKBIM, High Performance and Grid Computing Center (TRUBA Resources).

\section{REFERENCES}

[1] Zhang Y.Y., Ren N., Xu S.L., Zhang J.J., Zhang D.H., A series of binuclear lanthanide (III) complexes: crystallography, antimicrobial activity and thermochemistry properties studies Journal of Molecular Structure 2015; 1081: 413-25.

[2] Protogeraki C., Andreadou E.G., Perdih F., Turel I., Pantazaki A.A., Psomas G., 
Cobalt(II) complexes with the antimicrobial drug enrofloxacin: Structure, antimicrobial activity, DNAand albumin-binding European Journal of Medicinal Chemistry 2014; 86: 189201.

[3] Zamani F., Zendehdel M., Mobinikhaledi A., Azarkish M., Complexes of $\mathrm{N}, \mathrm{N}-b i s$ (salicylidene) 4,5-dimethyl-1,2-phenylenediamine immobilized on porous nanomaterials: Synthesis, characterization and study of their antimicrobial activity Microporous and Mesoporous Materials 2015; 212: 18-27.

[4] Babahan I., Emirdağ-Öztürk S, Poyrazoğlu-Çoban E, Spectroscopic and biological studies of new mononuclear metal complexes of a bidentate $\mathrm{NN}$ and NO hydrazone-oxime ligand derived from egonol Spectrochimica Acta Part A: Molecular and Biomolecular Spectroscopy 2015; 141: 300-6.

[5] Vural H., Uçar I., A combined theoretical and experimental study of chelidamate cadmium (II) complex, $\left[\mathrm{Cd}_{2}(\mathrm{dpa})_{2}(\mathrm{chel})_{2}\right] \cdot 2[\mathrm{Cd}(\mathrm{dpa})(\mathrm{chel})]$. $6 \mathrm{H}_{2} \mathrm{O}$ Spectrochimica Acta Part A: Molecular and Biomolecular Spectroscopy 2015, 136, 1298-307.

[6] Demirbaş U, Bayrak R, Piskin M, Akçay H.T., Durmus M, Kantekini H., Synthesis, photophysical and photochemical properties of novel tetra substituted metal free and metallophthalocyanines bearing triazine units Journal of Organometallic Chemistry 2013; 724: 225-34.

[7] Kumar V, Ahamad $\mathrm{T}$, Nishat $\mathrm{N}$, Some $O, O^{\prime}, O^{\prime \prime}, O^{\prime \prime \prime}$-di/tetra

aryldithioimidophonate transition metal complexes derived from catechol and bisphenol-A as antibacterial and antifungal agents European Journal of Medicinal Chemistry 2009; 44: 785-93.
[8] Raman N., Mahalakshmi R., Bio active mixed ligand complexes of $\mathrm{Cu}(\mathrm{II})$, $\mathrm{Ni}(\mathrm{II})$ and $\mathrm{Zn}(\mathrm{II})$ : Synthesis, spectral, XRD, DNA binding and cleavage properties Inorganic Chemistry Communications 2014; 40: 157-63.

[9] Sayin K., Karakas D., Karakus N., Alagöz Sayin T., Zaim Z., Erkan Kariper S., Spectroscopic investigation, FMOs and NLO analyses of $\mathrm{Zn}(\mathrm{II})$ and $\mathrm{Ni}(\mathrm{II})$ phenanthroline complexes: A DFT approach Polyhedron 2015; 90: 139-46.

[10] Üngördü A., Tezer N., Effect on frontier molecular orbitals of substituents in 5position of uracil base pairs in vacuum and water, Journal of Theoretical and Computational Chemistry 2017; 16: 1750066.

[11] Ozbakir Isın D., Karakuş N., Quantum chemical study on the inhibition efficiencies of some sym-triazines as inhibitors for mild steel in acidic medium, Journal of the Taiwan Institute of Chemical Engineers 2015; 50: 30613.

[12] Sun J., ding J., Liu N., Yang G., Li J., Detection of multiple chemicals based on external cavity quantum cascade laser spectroscopy, Spectrochimica Acta Part A: Molecular and Biomolecular Spectroscopy 2018; 191: 532-38.

[13] Üngördü A., Tezer N., DFT study on metal-mediated uracil base pair complexes, Journal of Saudi Chemical Society 2017; 21: 837-44.

[14] Zhu Q., Wen K., Feng S., Guo X., Zhang J., Benzimidazobenzothiazole-based highly-efficient thermally activated delayed fluorescence emitters for organic light-emitting diodes: A quantum-chemical TD-DFT study, Spectrochimica Acta Part A: Molecular and Biomolecular Spectroscopy, 2018; 192: 297-303. 
[15] GaussView 5.0, Gaussian Inc., Wallingford, CT, USA, 2009.

[16] Gaussian 09, rev. C.01, Gaussian Inc., Wallingford, CT, USA, 2010.

[17] PerkinElmer, 2012. ChemBioDraw Ultra Version (13.0.0.3015), CambridgeSoft Waltham, MA, USA.

[18] Rappe A.K., Casewit C.J., Colwell K.S., Goddard III W.A., Skiff W.M., UFF, a full periodic table force field for molecular mechanics and molecular dynamics simulations Journal of the American Chemical Society 1992; 114: 10024-35.

[19] Becke A.D., Density-functional thermochemistry. III. The role of exact Exchange The Journal of Chemical Physics 1993, 98, 5648-5652.

[20] Lee C., Yang W., Parr R.G., Development of the Colle-Salvetti correlation-energy formula into a functional of the electron density Physical Review B 1988; 37: 785-9.

[21] Jr. Dunning T.H., Hay. P. J., Schaefer III H.F., (Eds). in Modern Theoretical Chemistry, Vol. 3, Plenum, New York, 1977.

[22] Hay P. J., Wadt W.R., Ab initio effective core potentials for molecular calculations. Potentials for the transition metal atoms Sc to $\mathrm{Hg}$ The Journal of Chemical Physics 1985; 82: 270-83.

[23] Wadt W.R., Hay P. J., $A b$ initio effective core potentials for molecular calculations. Potentials for main group elements $\mathrm{Na}$ to $\mathrm{Bi}$ The Journal of Chemical Physics 1985; 82: 284-298.

[24] Sayin K., Karakaş D., Method/Basis Set Investigation and Spectral Studies for Oximato-Bridged trans-Platinum(II) Dimer Used as Anticancer Drug Journal of New Results in Science 2015; 8: 1-12.

[25] Sayin K., Erkan Kariper S., Alagöz Sayin T., Karakas D., Theoretical spectroscopic study of seven zinc(II) complex with macrocyclic Schiff-base ligand Spectrochimica Acta Part A: Molecular and Biomolecular Spectroscopy 2014; 133: 348-56.

[26] Sayin K., Karakaş D., Determination of structural and electronic properties of [Ni(NQSC)2] and [Ni(NQTS)2] complexes with DFT method Journal of New Results in Science 2013; 2: 47-53.

[27] Sayin K., Karakaş D., Quantum Chemical Studies on $[\mathrm{Co}(\mathrm{ntb})(\mathrm{pic})]+$ Complex Ion Journal of New Results in Science 2013; 2: 54-9.

[28] Güveli Ş., Özdemir N., Bal-Demirci T., Ülküseven B., Dinçer M., Quantumchemical, spectroscopic and X-ray diffraction studies on nickel complex of 2-hydroxyaceto phenone thiosemi carbazone with triphenylphospine Polyhedron 2010; 29: 2393-403.

[29] Erdik E., Organik Kimyada Spektroskopik Yöntemler, 2nd Edition, Gazi Kitaßevi: Ankara, Turkey, 1998. 